Ivan Rocha Ferreira da

Silva, MD

Jennifer Ann Frontera,

MD

Osvaldo Jose Moreira do

Nascimento, MD, PhD

Correspondence to

Dr. Osvaldo J.M. Nascimento: osvaldo_nascimento@hotmail.com

\section{NEWS FROM THE BATTLEFRONT: ZIKA VIRUS-ASSOCIATED GUILLAIN-BARRÉ SYNDROME IN BRAZIL}

In the wake of the Zika virus (ZIKV) epidemic, international resources have been dedicated to combating the increasing rates of ZIKV-associated microcephaly. However, other severe neurologic complications, such as Guillain-Barré syndrome (GBS), have received less attention and funding. In July 2015, 76 patients with recent symptoms suggestive of ZIKV infection with neurologic syndromes were identified in the state of Bahia, northeast Brazil, of which 42 (55\%) were confirmed GBS. ${ }^{1}$ In November 2015, the Aggeu Magalhães Research Center of the Oswaldo Cruz Foundation reported that ZIKV infection was found in 10 out of 224 suspected dengue cases. ${ }^{1}$ Seven of the 10 positive samples belonged to patients with a neurologic syndrome.

In November 2015, we created a self-funded study group in Rio de Janeiro, Brazil, involying neurologists, radiologists, and critical care and emergency medicine specialists to gather more precise/epidemiologic information regarding ZIKV-associated neurologic illnesses in adults (including GBS, meningoencephalitis, and transverse myelitis) and to help coordinate care of these patients (the RIO GBS-ZIKV Research Network).

The utilization of new, wireless technologies has been instrumental to information sharing for this network, particularly within underdeveloped regions of our catchment area, where infrastructure can be rudimentary. Short message service has been used during outbreaks of Ebola ${ }^{2}$ and $\mathrm{H} 1 \mathrm{~N} 1,{ }^{3}$ but our utilization of encrypted group messaging with smartphone apps (WhatsApp) allows groups of neurologists and researchers to instantly identify new cases and review and evaluate diagnostic tests such as nerve conduction studies, EMG, CSF analyses, and MRI. Because WhatsApp utilizes end-to-end encryption, ${ }^{4}$ all patient data are confidential and this communication technique has been sanctioned by our hospital network. We have also standardized data collection and protocolized treatment strategies within our network. In regions without a neurologic specialist, our group has been able to offer remote consultation. Social media has been used as well to propagate information on ZIKVassociated neurologic complications. The Brazilian Ministry of Health (BMH) created a YouTube channel to publish videos explaining the most common symptoms of ZIKV infection, how to detect and extinguish foci of Aedes aegypti, as well as the current evidence on microcephaly and GBS. In addition, a Facebook page and Twitter account were created to disseminate information. Google has also partnered with United Nations Children's Emergency Fundto create a platform to map and anticipate potential outbreaks.

Between December 5, 2015, and March 18, 2016, we identified 20 confirmed GBS cases referred to our university through our network, located in the state of Rio de Janeiro, Brazil. This volume of patients with GBS exceeds the 16 cases reported at our center over 24 months in 2013 and 2014 (prior to the ZIKV outbreak). This represents an increase from an average of 0.67 GBS cases per month to 5.4 cases per month. Of these 20 GBS cases, 17 were associated with a viral prodrome consistent with ZIKV (pruritic rash, fever, or arthralgias). Of note, only $20 \%$ of patients with ZIKV infection are thought to develop florid symptoms. ${ }^{5}$ The association of GBS and ZIKV has also been observed in French Polynesia, ${ }^{6}$ where the predominant form of GBS reported was acute motor axonal neuropathy (AMAN). In our genetically distinct population, we have observed ZIKV-related AMAN, acute motor sensory polyneuropathy, acute inflammatory demyelinating polyradiculoneuropathy, chronic inflammatory demyelinating polyradiculoneuropathy, and Miller Fisher variant. In addition, cases of encephalitis, transverse myelitis, and acute disseminated encephalomyelitis following a ZIKV prodrome have presented to our facility.

The RIO GBS-ZIKV Research Network has increased transfers to our central, tertiary hospital, as well as referrals to our outpatient neurology subspecialty clinics. Though most local hospitals have intensive care units (ICUs) with ventilator capability, we have found that specialized neurocritical and neuromuscular care offers more rapid assessment (EMG/nerve conduction

From the Neurology Department (I.R.F.d.S., O.J.M.d.N.), Universidade Federal Fluminense, Niteroi; Neurocritical Care Unit (I.R.F.d.S.), Americas Medical City, Rio de Janeiro, Brazil; and Neurocritical Care Department (J.A.F.), Cleveland Clinic Foundation, OH. Go to Neurology.org for full disclosures. Funding information and disclosures deemed relevant by the authors, if any, are provided at the end of the article. 
studies, MRI, ZIKV molecular and serologic testing) and aggressive management of these patients (e.g., IV immunoglobulin, plasmapheresis, steroids). A consequence of the increased rate of ZIKV-related neurologic illnesses has been the strain this has placed on ICU bed capacity (which is already limited in developing nations). In some circumstances, patients are managed in the emergency department or regular floor by intensivists until an ICU bed becomes available. Because GBS can be incapacitating, often requiring ICU admission and mechanical ventilation, increased efforts directed toward prevention and early intervention are merited.

Our next step, in collaboration with the State of Rio de Janeiro Health Department and the BMH, is the creation of a hotline where physicians can discuss, refer, and transfer possible cases to tertiary centers for further analysis and treatment. As part of this effort, a national registry of patients with neurologic complications deemed secondary to ZIKV infections is being developed.

We have been able to harness low-cost, instant communication and mass media to develop a technologybased system for combating the ZIKV epidemic. Such a network could potentially be replicated in other countries affected by similar outbreaks.

\section{AUTHOR CONTRIBUTIONS}

Ivan Rocha Ferreira da Silva: study design, data collection, manuscript writing. Jennifer Ann Frontera: study design, data collection, manu- script writing. Osvaldo Jose Moreira do Nascimento: study design, manuscript writing.

\section{STUDY FUNDING}

No targeted funding reported.

\section{DISCLOSURE}

The authors report no disclosures relevant to the manuscript. Go to Neurology.org for full disclosures.

\section{REFERENCES}

1. PAHO/WHO. Epidemiological Update: Neurological Syndrome, Congenital Anomalies, and Zika Virus Infection: 17 January 2016. Pan American Health Organization/World Health Organization; 2016. Available at: http://www. paho.org/hq/index.php?option $=$ com_docman\&task $=$ doc view\&Itemid $=270 \&$ gid $=32879 \&$ lang $=$ en. Accessed March 20, 2016.

2. Tracey LE, Regan AK, Armstrong PK, Dowse GK, Effler PV. EbolaTracks: an automated SMS system for monitoring persons potentially exposed to Ebola virus disease. Euro Surveill 2015;20:20999.

3. Chai SJ, Tan F, Ji Y, Wei X, Li R, Frost M. Communitylevel text messaging for $2009 \mathrm{H} 1 \mathrm{~N} 1$ prevention in China. Am J Prev Med 2013;45:190-196.

4. WhatsApp. Available at: https://www.whatsapp.com/faq/ en/general/28030015. Accessed June 3, 2016.

5. Duffy MR, Chen TH, Hancock WT, et al. Zika virus outbreak on Yap Island, federated states of Micronesia. N Engl J Med 2009;360:2536-2543.

6. Cao-Lormeau VM, Blake A, Mons S, et al. Guillain-Barre syndrome outbreak associated with Zika virus infection in French Polynesia: a case-control study. Lancet 2016;387:1531-1539. 


\section{Neurology}

News from the battlefront: Zika virus-associated Guillain-Barré syndrome in Brazil

Ivan Rocha Ferreira da Silva, Jennifer Ann Frontera and Osvaldo Jose Moreira do

Nascimento

Neurology 2016;87;e180-e181 Published Online before print July 15, 2016

DOI 10.1212/WNL.0000000000003024

This information is current as of July 15, 2016

\section{Updated Information \&} Services

References

Citations

Subspecialty Collections

Permissions \& Licensing

Reprints including high resolution figures, can be found at: http://n.neurology.org/content/87/15/e180.full

This article cites 4 articles, 0 of which you can access for free at: http://n.neurology.org/content/87/15/e180.full\#ref-list-1

This article has been cited by 1 HighWire-hosted articles: http://n.neurology.org/content/87/15/e180.full\#\#otherarticles

This article, along with others on similar topics, appears in the following collection(s):

Autoimmune diseases

http://n.neurology.org/cgi/collection/autoimmune_diseases

Critical care

http://n.neurology.org/cgi/collection/critical_care

Guillain-Barre syndrome

http://n.neurology.org/cgi/collection/guillainbarre_syndrome

Post-infectious

http://n.neurology.org/cgi/collection/postinfectious_

Public health

http://n.neurology.org/cgi/collection/public_health

Underserved populations

http://n.neurology.org/cgi/collection/underserved_populations

Information about reproducing this article in parts (figures,tables) or in its entirety can be found online at:

http://www.neurology.org/about/about_the_journal\#permissions

Information about ordering reprints can be found online:

http://n.neurology.org/subscribers/advertise

Neurology ${ }^{\circledR}$ is the official journal of the American Academy of Neurology. Published continuously since 1951, it is now a weekly with 48 issues per year. Copyright () 2016 American Academy of Neurology. All rights reserved. Print ISSN: 0028-3878. Online ISSN: 1526-632X.

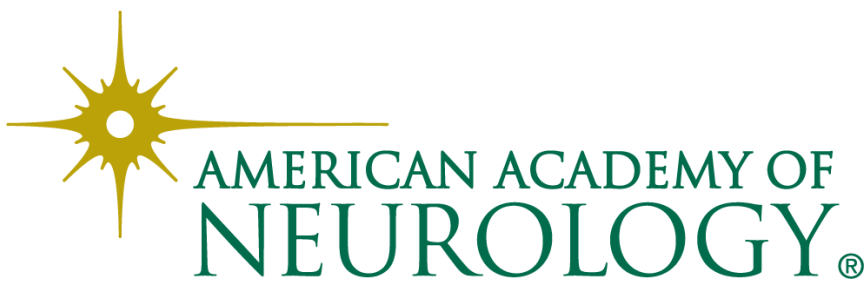

